\title{
The Civil Liability of Street Shooting and Photography Under the Jordanian Civil Law
}

\author{
Dr. Enas Qutieshat* \\ Philadelphia University
}

\begin{abstract}
People like to capture the moment and recall it upon request. Nearly everyone is able to take photos using standard technology. This paper will highlight one of the most important cases where photos are taken in good or bad intentions without the consent of the individual being captured. Any individual has the right to privacy in his personal life; this means he has the right to control who will have the right to capture his photo and who has the right to use it in the future. This is so, since there are some rights, which are recognized by different national laws and international conventions connected to human beings. In Jordan, any individual has some basic rights, including but not limited to the right of privacy and the right to protect others from brining any action against the rights, which are connected to their legal personality as a human being. This paper will highlight the current legal approach within Jordan when it comes to taking photos of other. Trying to figure out whether the laws, as is, are able to protect individuals or need to be amended.
\end{abstract}

Keywords: Civil Liability, Privacy, Photography, Consent, Breach.

DOI: $10.7176 / \mathrm{JLPG} / 91-14$

Publication date: November $30^{\text {th }} 2019$

\section{Introduction}

The world is experiencing a fast-technological change in all aspects. The current generation is known to as the first digital generation. Technology has brought massive growth and changes in the past half-decade, with tools that are more advanced, equipment, medication, or machines meant to improve life quality or make living simpler, as it is commonly referred. However, technology has dragged along several disasters, such as advanced weapons, employment crisis, child abuse, sophisticated crimes, and social disconnect, among many more. In addition, technology has introduced gray areas in law and defining what is right or wrong. Among such cases where there lies a confusing issue in the Jordanian law is street shooting, photography, and breach of personal the privacy and their rights of photo.

Photography has benefited massively from technological advancement. Currently, there are people benefiting millions from photography, either as photographers, photo editors, or running online galleries. There are photos earning millions of monies due to different reasons such as the items or people photographed what they portray, or the moment they represent. Different types of cameras with the most advanced technology have been innovated, ${ }^{1}$ with companies such as Niko, Canon, and Sony making billions of dollars in profit. Phone cameras have also increasingly improved. ${ }^{2}$ The most prominent companies in the industry competing to produce the best phone cameras, given it is one of the qualities most customers want. Recently, small hidden cameras had become readily accessible on the market, with affordable prices, unlike about five years ago when they were very expensive. Almost everyone with a smartphone tries to capture "the moment" whenever a situation arises.

With all the cameras' advancement, street shooting and photography has become a regular practice done by both photographers and civilians. With photographers, taking pictures is their job, while civilians only take pictures to capture "the right moment", therefore only on special occasions. Most people taking street pictures do it with the right intentions. However, in some cases, especially when the photograph is taken without permission, legality questions arise. There are hundreds of websites buying, selling, or posting such pictures and benefiting from illegally obtained photos, ${ }^{3}$ yet attract millions of viewers. ${ }^{4}$ With no clear law defending the civilians of street shootings and photography in public places, the practice will continue affecting innocent people from all possible angles.

\subsection{Problem of the Study}

Street shooting and photography can have devastating consequences on civilians. Photos such as crime scenes, individuals in war, or shock, which are taken with the wrong or right intention, would expose one to many negative possibilities related to sharing photos online. Even while taking a photo for acceptable reasons, they can eventually have an everlasting effect on an individual. In some cases, one can find heated discussions about their

${ }^{1}$ Edwards, E. (2016). Photography, anthropology and history: expanding the frame. Routledge.

${ }^{2}$ Zeronda, N.D., 2010. Street Shootings: Covert Photography and Public Privacy. Vand. L. Rev., 63, p.1131.

${ }^{3}$ Marvin, J. T. (2015). Without a bright-line on the green line: How Commonwealth v. Robertson failed photography. New Eng. L. Rev., 50, 119. 
pictures that they did not know exists. When these talks are harmful, such as body shaming and cyberbullying, one can get adverse psychological problems that would take a lifetime to heal. Therefore, there should be existing laws to protect the public from such situations.

However, currently, there are no clear laws directly making street shooting and photography illegal, even when the photos may have an everlasting negative impact on one's life. In most cases, the law protects the photographer, under Law No. 8 of 1998 (Press and Publication Law of 1998) ${ }^{1}$ and Article 26 of Law on the Protection of Copyright ${ }^{2}$ where original artwork, which includes photographs, has legal protection. ${ }^{3}$ Having said that, both previous laws had set out some limits when it comes to the breach of personal life. Furthermore, the civil labiality within the Jordanian Civil Code. ${ }^{4}$ will help in protecting the privacy of personal life from being breached by photography actions.

\subsection{Importance of the Study}

Given the importance of the topic due to the impacts it could pose on an individual's life, the study is meant to benefit people in several ways. One of the major significances of the study is identifying the fact that street shooting and photography endangers innocent civilians' life. Many people have found themselves in a position where their photos are taken without their consent, only for them to feel offended, but not realizing it is a growing problem affecting millions around the world. For the photographers taking pictures of people on the streets, not understanding the adverse effects they pose on civilians, they will learn that the act is might indeed be considered as harmful. In addition, it will sensitize the public on why they should avoid taking pictures of strangers in public places.

Identifying the problem will help make the general public and the authorities on the need to have a clear law that protects everyone against street shooting and photography. The law needs to evolve with time as the world faces new problems that were previously unknown. With a clear law defining the legality of the act, many people involved will refrain from taking unpermitted photos, while those caught will face the full force of the constitution accordingly.

Finally, the study will educate readers on the presence of a law that can be interpreted to protect them from street shooting and photography. Since the law does not directly relate to street photography, most civilians might not understand how civil liability law protects them from the issue. With the knowledge that the law protects one from unpermitted street photography, one can have the confidence to report incidences to the right authority. Thus, the study will help civilians solve these issues where, in most cases, they go unreported.

\subsection{Objectives of the Study}

General objective. The research is meant to identify how street shooting and photography affect innocent civilians, thus requiring the introduction of a clear law or legal provisions within the current laws that defines the act as illegal.

\section{Specific objectives}

- To identify street shooting and photography as a problem affecting many civilians and explain the dangers of street shooting and photography poses to innocent civilians in public places.

- Explain why the problem of street shooting and photography is a breach of the right to privacy.

- Identifying the need for a clear law defining street shooting and photography as an illegal activity with set consequences.

- Identify how and why street shooting and photography can be interpreted under civil liability law.

- Identify why street shooting photographers are liable for harm caused by the photos they take.

- To raise the alarm about the problem, thus, creating a room for further research on the issue.

\subsection{Methodology}

This research will be carried out using various methods of research, starting with the explanatory work and determining the conceptual framework, principles, legal rules and caselaw that is relevant to the subject matter. The paper will also try to highlight the best legal solution for the case of street shooting and photography. The paper will present the subject matter descriptively since the primary goal of the study is to provide exhaustive and comprehensive information regarding street shootings and photography in relation to the law.

\footnotetext{
${ }^{1}$ Press and Publication Law of 1998 and its amendments, published in the Official Gazette number 4300 page 3162 date $1 / 9 / 1998$. (hereinafter will be refered to as Press and Publication Law of 1998)

${ }^{2}$ Law on the Protection of Copyright and its amendments, published in the Official Gazette number 3821 page 684 date 16/4/1992.

${ }^{3}$ Mulki, F. (2008, December). Implementing national copyright laws: a Jordanian case study. In Proceedings of the 2nd international conference on Theory and practice of electronic governance (pp. 191-198). ACM.

${ }^{4}$ The Jordanian Civil Code, Law No. 43 of 1976 and its amendments, published in the Official Gazette number 2645 page 2 date $1 / 8 / 1976$. (hereinafter will be referred to as JCC).
} 


\subsection{Previous Studies}

Many papers were found relevant to the subject matter of Street shooting and photography. Street shooting and photography has faced several controversial studies, where some researchers are against it, while others support it. According to Miles, taking pictures in public places is allowed legally in almost all parts of the world. ${ }^{1}$ Therefore, as long as anything, including people, are in the vicinity of a public view, a photographer can take a picture and turn it into a piece of art. Since Henri Cartier-Bresson, a famous twentieth-century, pioneered street photography, some people have openly opposed the act, referring it as a breach of privacy. ${ }^{2}$ On the other hand, others argue that since it is done in the street, there is nothing private in public. ${ }^{3}$ Street photographers have since been concealing their cameras or identity, walking about and around, waiting for the right moment to capture targets or random moments, or people in a candid posture. ${ }^{4}$

Compared to the twentieth-century, it has become more difficult to spot photographers. During those days, cameras were large and required one to conceal both their equipment and identity. ${ }^{5}$ In addition, photographers had to stick in one location, since moving with the camera around would reveal their identity and intentions. ${ }^{6}$ For example, Cartier-Bresson had to wrap his camera with black tape to hide the shiny parts from people who could notice it. ${ }^{7} \mathrm{He}$ also had to cover his face with a handkerchief or pretend to be blowing his nose while taking a picture. Due to such types of hustles, there were few street photographers, while those partaking the act rarely had chances to capture many images. ${ }^{8}$

Today, photographers are armed with small cameras that do not need concealment. There are cameras with the size of an average blazer button. Phone cameras have been developed to have megapixels higher than the camera used in the twentieth century, thus taking photos that are more explicit. ${ }^{9}$ According to Scott, such equipment is affordable for most people. ${ }^{10}$ There are also cameras taking pictures from meters away. Therefore, street shooting and photography has become common, with photographers having the capability to shoot from distances away, and using any angle. Thus, with the camera technology advancing, so is the potential to harm more people.

According to Miles, the rise in demand for photos in the world has fueled the danger of civilians being exposed to street photography. ${ }^{11}$ The current most harmful market that has endangered people is hundreds of websites paying for upskirt, memes, and jokes images that may entail body shaming or humiliating messages. Zeronda, states that almost all upskirt, crime scenes, and individuals in war, shock, or at the hospital pictures are taken without consent, and display parts of a person's life that would not have been seen with the naked eye. ${ }^{12}$ Memes, especially those edited to portray body shaming or with inserted messages that can humiliate the photographed have also become a problem. Such photos end up stripping one's dignity and leaving them with a phycological issue.

In a research on tourist photography ethics titled "Gazes and faces in tourist photography", ${ }^{13}$ the authors reached a conclusion that despite the permissions to take pictures, most locals did not allow total camera freedom. ${ }^{14}$ Tourism and photography go hand in hand, given that images represent memories of the visited areas. ${ }^{15}$ The research states that tourists take pictures with the desire to share and re-live extraordinary moments. Most tourists are street photographers by nature, though with acceptable intentions. However, there is always a question on what and what not to photograph. Most travel companies highlight ethical issues a tourist should uphold. Such ethical issues include information on what to shoot and areas to avoid the use of cameras. ${ }^{16}$ Tourism ethics in photography are one-sided. The industry is very competitive, making every company fight for customers under any cost. Therefore, companies only give information that favors tourists, such as locations that should not be photographed. Most tourists end up taking pictures of everything else, including local children and adults. In some cases, the tourists are met with a harsh response from offended photographed locals. ${ }^{17}$ The research suggested that despite the fact of freedom to shoot, tourists need to ask for permission from the people

\footnotetext{
${ }^{1}$ Miles, M., 2015. Photography, privacy and the public. Law, Culture and the Humanities, 11(2), pp.270-293.

2 Zeronda, (fn1) 1132.

${ }^{3}$ Gillespie, A. (2006). Tourist photography and the reverse gaze. Ethos, 34(3), pp.343-366.

${ }^{4}$ Zeronda, (fn1) 1132.

${ }^{5}$ Zeronda, (fn1) 1132.

${ }^{6}$ ibid.

${ }^{7}$ ibid1132.

${ }^{8}$ ibid 1133

${ }^{9}$ Meltzer, S. (2014, May). The ease of digital photography turns every shutterbug into a potential copyright pirate. Look, but Do Not Shoot.

${ }^{10}$ Scott, C., 2013. Street Photography: From Atget to Cartier-Bresson. IB Tauris.

${ }^{11}$ Miles, (fn1) 272.

12 Zeronda, (fn1) 1132

${ }^{13}$ Höckert, Höckert, E., Lüthje, M., Ilola, H. and Stewart, E. (2018). Gazes and faces in tourist photography. Annals of Tourism Research, 73.

14 ibid 140.

${ }^{15}$ Gillespie, (fn1) 344.

${ }^{16}$ Höckert, (fn1) 137.

${ }^{17}$ Gillespie, (fn 1) 348
} 
they would want to photograph.

A study titled the "Civil Liability of the Journalist for the Violation of the Right to the Image in Jordanian $L a w^{\prime \prime} ;{ }^{1}$ the author has discussed the subject matter by focusing on the work of the journalist only. The paper examined whether traditional rules of the civil liability could be applied to the work of the journalist and how reaching the public with news and reports could might put the journalist at risk of compensation. Other relevant paper related to the work of the journalist is a paper titled "Towards a Legal System for the Journalist's Civil Responsibility for Displaying Images of Victims of Crime"2 the author also discussed whether the journalist is liable to any kind of responsibility if he carried out his work and used photos of victims.

\subsection{Research Plan}

To answer the research questions, this paper was divided into five section. The first one is the Introduction, in which the author of the paper highlighted the problem of the study and its importance and objectives. It also had a section on previous studies related to the topic. Next, the research had a section titled: The Right of Privacy and Photography. This section will explain and expound the right to privacy. The context of the right will be discussed, and linked to the research problem. Various aspects of photography, such as history, its growth over time, and current trends, will follow next. Ethic issues and problems associated with photography. This section will also discuss one of the most important rights connected to the legal personality of human beings; i.e. the person's right to photography. The research will then connect the second section to civil liability under a section titled as The Right of Photography v. The Civil Labiality, explaining how the problems will cause, damages, and the link between the cause and injuries. The next section, which is titled as The Legal Consequences and Treatment of Photography, will give examples of previous cases involving photography, both in Jordan and other parts of the world will be discussed as evidence of the issue as an existing problem that requires an immediate solution. Finally, a conclusion and recommendation, based on the study will be given.

\section{The Right to Privacy and Photography}

When it comes to the personal life of individuals, the Jordanian law recognize that every person in the society whether Jordanian or non-Jordanian has the right to privacy and the right to be protected from any act which might interfere with the rights that are recognized and linked to his personality. The Jordanian Constitution expressly recognizes that everyone in the country has a right to privacy. ${ }^{3}$ However, with the technology advancing, some parts of the current traditional legal rules may be challenged. Photography challenges the right to privacy and the right of personal photo and image, which are linked to the legal personality of human beings. Even with the existence of some laws that might help in the protection of the right of privacy and the personal image of person people still suffer from humiliating images distributed offline or online without their consent.

\subsection{Definition of photography}

Nowadays, photos can express more than words. Photos are able to transfer real events and moment in a durable medium which can be carried over from place to another physically or electronically. "Photography" has been defined by article 10 of Instructions for Products of Chemical or Related Industries for 2012 as "the process by which visual images are formed directly or indirectly, by light or other forms of radiation on light-sensitive surfaces." 4

Photography technique dates back in the 1820s when Nicephore Niepce invented a process called heliography, which fixed an image on a silver plate. ${ }^{5}$ For the process to be successful, the image had to be exposed to the camera for several days. After Niepce's death in 1838, Louis Daguerre, his associate came up with the daguerreotype process, which was improved heliography since images required a few minutes of exposure. ${ }^{6}$ The daguerreotype process was the first photographic process to be announced publicly and sold. During the same time, paper-based photography was discovered, and since then there have been massive innovations, up to the invention of the portable handheld camera by Kodak in the 1880s. ${ }^{7}$ Later in the year 1957, the first binary camera, which allowed soring of images in computer memory, was invented. Today there exists even more cutting edge in camera technology, where one can easily purchase small cameras with the size of an average button.

\footnotetext{
${ }^{1}$ Khasawneh, M ' Civil Liability of the Journalist for the Violation of the Right to the Image in Jordanian Law' (2015) 12 University of Sharjah Journal of Islamic and Legal Studies 197.

${ }^{2}$ Almozani, J and Almozani , K (2008) " Towards a Legal System for the Journalist's Civil Responsibility for Displaying Images of Victims of Crime" 7 Center for Kufa Studies 96.

${ }^{3}$ The Jordanian constitution, art. 7.

${ }^{4}$ Art. 10 Instructions for Products of Chemical or Related Industries for 2012 and its amendments published in the official gazette issue number 115 date 01/01/2012.

${ }^{5}$ Edwards, E. (2016). Photography, anthropology and history: expanding the frame. Routledge.

${ }^{6}$ ibid.

7 ibid.
} 
Many types of photography have continually been developed since the discovery of cameras. Street photography is one of the primary types, meant to capture unmediated random images in public places. Street shooting and photography has been around since the early age of camera development, but Henri CartierBresson introduced the concept in the twentieth century. ${ }^{1}$ Cartier-Bresson is one of the earliest owners of the $35 \mathrm{~mm}$ camera developed by the Kodak Company. Street photography has since been developed to become a career pursued by people, a course offered in schools, and inspiring books. The art of photography was also the motivation Brandeis and Warren to write their article: "The Right to Privacy" in $1890 .^{2}$

\subsection{Definition of Person's Right to Photography}

Person has certain rights, which are recognized by treaties, conventions and local laws such as the right to right to life, liberty and security. ${ }^{3}$ Any person has definite rights, which has connected with him as "human being" such as the right to be protected from any harmful acts brought against his body. An infringement of such rights creates a right for the offender to be compensated, and the right to compensation arises even if the case is related to physical or moral damages. ${ }^{4}$ Rights which are associated with legal personality as mentioned earlier, are also linked to "living" human being, as a result, such rights will end with the death of this human being. In other words, the death of a person means the end of his personality and any rights associated with this personality. This leads to the fact that the heirs cannot initiate claims for these rights, except their right for compensation based on the moral damage cause to the person's reputation as defamation or slander; as such claim is transferred to the heirs. ${ }^{5}$

Street shooting and photography as an "act" is not illegal. Buying and selling cameras and other recording devices and materials is easy within the local and international market. People like to take photos of person, nature, events and other spots in their daily like for many reasons. One who take a photo should not be asked to have legal permission, unless the law request to do so. For example, a visitor to a historical place is allowed to take photos without a need to permission from the local authorities. 6 While in other cases, a permission is needed such as filming for the purpose of promoting Petra nationally and international. ${ }^{7}$ While in other cases photography and recoding images is prohibited. ${ }^{8}$

One might argue that recalling memories does not need any legal document or consent of the strangers to take their pictures in public. ${ }^{9}$ This includes photos of private property or people in their homes, taken from a public view where their appearance in the photo was secondary factor. Therefore, the right to privacy is commonly questioned when it comes to street shooting and photography. Internationally, most countries' constitutions have articles regarding the right to privacy. ${ }^{10}$ Initially, the right to privacy was a concept introduced by Professor Samuel Warren, a Boston attorney, and Louis Brandeis, a Supreme Court justice of the United States. ${ }^{11}$ The two published an article titled, The Right to Privacy in the Harvard Law Review in the year $1890 .{ }^{12}$ In the article, they articulated the right as "the right to be left alone". According to the article, the law needed to change as technology advanced, since the press, government, and other institutions could invade aspects of personal life that were inaccessible in previous eras. The rising growth of print media and innovation of smaller, affordable cameras sold by Kodak concerned the two as a factor that endangered "the right to be left alone." The article also notes that the presence of instantaneous photographs invaded privacy that was previously enjoyed by people. ${ }^{13}$ The two also argued that invasion of privacy would cause psychological distress and pain that is worse than bodily injury. The article concluded by recommending that the law should be changed to include clear boundaries between private and public life, to protect people.

When considering issues related to the right of privacy, questions might raise when it comes to the

\footnotetext{
${ }^{1}$ Miles, (fn1) 273.

2 Zeronda, (fn1) 1132.

${ }^{3}$ The Office of the High Commissioner for Human Rights Universal Declaration of Human Rights, art. 3

${ }^{4}$ art. 276 of the JCC states that "the right to damages shall include moral damage, so any trespass on another's liberty, honor, reputation, social status or financial standing shall render the person who commits the trespass liable for damages.

${ }^{5}$ art 276 of the JCC states that:" 2.and damages may be awarded to spouses and close relatives in the family for the moral damages inflicted upon them by the death of the injured. 3. and liability for damages for moral damage shall not devolve upon others unless their amount is defined by virtue of a contract or a final judicial decision."

${ }^{6}$ art 5 Instructions for organizing tourism activities and events within the Petra Archaeological Reserve 2017 and its amendments published in the official gazette issue number 5464 date $01 / 06 / 2017$ page 3836 .

7 ibid, art $5 / 2 \& 3$

${ }^{8}$ Caselaw number 299/2018 of Court of First Instance. In this case photos were taken of military vehicle in which the prosecution witness, Lieutenant Ziad and a number of members of the patrol and the court in its judgement found that the actions taken by the suspects, and with the general knowledge that such action is a clear violation of the inviolability of the military and their whereabouts and mechanisms.

${ }^{9}$ Miles, (fn1) 276.

${ }^{10} \mathrm{ibid}, 272$

${ }^{11}$ Zeronda, (fn1) 1132

${ }^{12}$ Barron, J. H. (1979). Warren and Brandies, the Right to Privacy, 4 Harv. L. Rev. 193 (1890): Demystifying a Landmark Citation. Suffolk UL Rev., 13, 875

${ }^{13}$ Zeronda, (fn1) 1132.
} 
argument related to the freedom of expression argument. In the Jordan constitution, article 15 gives people freedom of expression, even in the form of photographic representation. ${ }^{1}$ Photographers are said to express opinions, tell stories, or communicate a societal aspect of a topic. ${ }^{2}$ The following section will highlight issues related to the Right to Photography and how could the Civil Labiality ring the alarm.

\section{The Right to Photography v. The Civil Labiality}

It is established that the person has the right to express his thoughts to the out world. The Jordanian constitution expressly stated, "[p]ersonal freedom is inviolable." ${ }^{3}$ Expressing thoughts and opinions could take many forms including but not limited to taking photos since the later are able to express and record the moment easily and at once. Having said that, article 8 of the Jordanian constitution has made it clear that "any attack on public rights and freedoms or the inviolability of the private life of Jordanians is a crime which is punishable by law."4 The freedom of expression could also be found within the Press and Publication Law. The later expressly stated: "the freedom of opinion is guaranteed to every Jordanian." ${ }^{5}$ Expressing opinions could be done freely in any medium including but not limited to speaking, writing, photographing, and drawing. ${ }^{6}$ The previous rules of the Press and Publication Law shall be applied to all Jordanians; however, the law also regulates the expressing of thoughts and opinion, which could be done in the course of journalism. As the law has limited the freedom in presenting news, information and any commentary work the journalism field. Their work has to be within the limits of the law and within the framework of preserving public freedoms, rights and general duties and respecting the freedom and privacy of others. ${ }^{7}$

Legal liability cases involve a party seeking legal action against another for injuries or loss caused by the defendant. Somewhat, the losing party compensates the winning side. ${ }^{8}$ Within the JCC, legal liability is divided into two types: contractual liability and tort or civil liability. ${ }^{9}$ Contract liability refers to harm caused when the defendant lacks to fulfill the requirements of the set agreement. It is the damages suffered by the plaintiff, due to breach of contract by the sued. On the other hand, tort liabilities are payments for damages caused to a party complainant, who are not under a contract. Effects of street shooting and photography fall under tort liabilities. Article 256 of the code requires three elements present to apply the rules of civil liability. The three include the error/fault, which is the cause or wrongdoing; the damage, which is the result of the wrongdoing; and a connection between the losses and the results. ${ }^{10}$ The following subsection will apply the three elements mentioned above to the case f street shooting and photography.

\subsection{The Cause: Wrong Doing}

As earlier stated, for civil liability, namely, the tort liability is to apply in a case; there must be a cause, which is the wrongful behavior that leads to intended or unintended damages. In this study, the cause includes actions that may harm people photographed in the streets or other places without their consent.

One might argue that that street shooting and photography is allowed, not knowing that legal consequences might raise when photos are being taken. Following are the types of street shootings that might be in question and considered as the first element of civil liability:

\section{Taking photos of ordinary individuals in public places:}

Applying the current legal rules of civil code means that a person has the right to forbid and stop others from taking their photos without their consent. Having said that, if the official authorities gave the permission to take photos of individuals in the public places, this such act will be considered as legal. ${ }^{11}$

\section{Taking photos of ordinary individuals in private places:}

This is strictly forbidden within the Jordanian law as it is considered a breach of the personal right of privacy according to the Jordanian criminal law ${ }^{12}$ if done without the legal consent of the person in photo. Article 348 of the JCL punishes any person who violates the private life of others either by hearing to sight including taking

\footnotetext{
${ }^{1}$ The Jordanian constitution (n 1) art. 15/1.

${ }^{2}$ Miles, (fn1) 275 .

${ }^{3}$ art. 8/1 the Jordanian Constitution. Also see article 7/b of Press and Publication Law of 1998 (fn1) which states that "freedom of thought, opinion, expression and access to the press and citizen alike."

${ }^{4}$ art. 8/2 the Jordanian Constitution. also see article 7/a of Press and Publication Law of 1998 (fn1) which expressly requires "[r]especting the public freedoms of others, preserving their rights and not harming the privacy of their private lives."

${ }^{5}$ art. 3 of Press and Publication Law of 1998 (fn1)

${ }^{6}$ ibid.

7 ibid, art. 4 .

${ }^{8}$ Manea, L. (2018). Constants of tort liability's. Bulletin of the Transilvania University of Braşov, Series VII: Social Sciences and Law, 11(2Suppl), 107-112

${ }^{9}$ Civil Code (fn 1).

${ }^{10}$ Manea, (fn1) 110

${ }^{11}$ art. 26 of Law on the Protection of Copyright (fn 1).

${ }^{12}$ The Jordanian Criminal Law number 16 of 1960 and its amendments, published in the Official Gazette number 1487 page 374 date 01/06/1960 (hereinafter JCL).
} 
photos of them by making him subject to imprisonment for a period of not less than six months and a fine of 200 Jordanian dinars, and such sanction will be doubled if the act is repeated. The act is also punishable according to the JCC as article 48 gave the right to take legal steps to stop any act brought against any violation to rights connected with legal personality and the right to be compensated.

\section{Taking photos of public figures in public places:}

The civil code does not distinguish between individuals, and its provisions shall be applied to all at the same level. However, the Jordanian Copyright Protection law has gave the right to take photos of official men or people of public fame. ${ }^{1}$ To apply this rule, this means that they were found in public places and in public events.

\section{Taking photos of public figures in their personal and private lives:}

In this case, such persons has the right to protect their personal life and privacy from being breached. Similar to ordinary individuals, public figures have that side of their life, which they tend to keep safe and away from others. As a result, article 48 of the JCC and article 348 of the JCL shall be applied.

\section{Taking photos of dead people:}

Since the law requires giving permission and consent to be photographed, one might ask about taking photos of dead people since they will not be in a state to give permission. The Jordanian General Iftaa' Department, has expressly stated that it is forbidden to take photos of injured to dead people as it is a violation of the inviolability of others and an assault on their dignity which is protected by the Islamic Sharia'a Law. ${ }^{2}$

Furthermore, the JCL also forbids any act that considered as a violation of the sanctity of the dead. ${ }^{3}$ Any person who violates the sanctity of the dead shall be subject to the penalty of imprisonment not less than three months and not more than two years.

6. Publishing and distributing of photos of ordinary individuals in private and public places or photos of public figures in their personal and private lives, or photos of photos of dead people:

This case is strictly forbidden whether the publishing and distributing done offline or online, ${ }^{4}$ and whether done by ordinary individuals or by the press. The first will be covered by the general rules of the JCC and JCL, while the latter is covered by article 38 of the Press and Publication Law of 1998 and article 20/L of Audiovisual Media Act of 2015 . $^{5}$

It must be noted that the law even in cases when it gave the permission to photograph individuals, it put a general rule not to display, publish, distribute or distribute any image if it results in a violation of the honor of the person you represent, or the substitution of his dignity, reputation, dignity or social status. ${ }^{6}$

With the rise of social media platforms, the world is now more connected than any other time in the history of humanity. The use of the internet and smartphones have contributed to the rise in social media connectivity. ${ }^{7}$ The number of smartphones bought globally has increased tremendously, while tech companies in the industry compete to produce either advanced or affordable gadgets. With social media and internet use, anything can go wrong within a second. In this case, a street photographer may -intentionally or unintentionally- cause a bodyshaming situation, which can spread all over the world within a short period. Currently, memes spread all over the globe within seconds. Memes, in this case, include edited pictures of individuals, or inserted messages that can humiliate an individual. The creation of memes that make fun of a picture taken in the street may cause permanent damage to an individual. ${ }^{8}$

Pictures may lead to other types of crimes, such as identity theft, and can be interpreted as stalking, which is a criminal offense. ${ }^{9}$ Identity theft is the case when one uses another person's picture as their identity, for favors, or financial benefits. This can include the creation of an online account by using a photo taken on the street. There have been several cases of people finding social media or other online platform accounts bearing their photographs. Such social media accounts may be used or get involved in criminal activities. Today, most images, especially those taken using mobile phones, contain geotag information, which may tell everyone viewing them

\footnotetext{
${ }^{1}$ art. 26 of Law on the Protection of Copyright (fn 1).

${ }^{2}$ Fatwa number 2948 date 24/01/2014 < https://www.aliftaa.jo/Question.aspx?QuestionId=2948\#.Xb7J29Izbcs> accessed 15/07/2018.

3 art. 277 of JCL.

${ }^{4}$ art. 11 of the cybercrime law (Law number 27/2015 published in the official gazette number 5343 date 01/06/2015 page 5631) "Whoever intentionally sends, resends or publishes data or information through the information network, website or any information system involving defamation, defamation or contempt of any person shall be punished by imprisonment for a period not less than three months and a fine of not less than (100) one hundred dinars. And not more than (2000) two thousand dinars."

${ }^{5}$ Law No. 26 of 2015 (Audiovisual Media Act of 2015) and its amendments, published in the Official Gazette number 5343 page 5614 date $01 / 06 / 2015$.

${ }^{6}$ art. 26 of Law on the Protection of Copyright (fn 1).

ibid.

${ }^{8}$ It must be noted that art. 11 of Cybercrime Act of 2015, No. 27 of 2015 stated that: "Whoever intentionally sends, resends or publishes data or information through the information network, website or any information system involving defamation, defamation or contempt of any person shall be punished by imprisonment for a period not less than three months and a fine of not less than (100) one hundred dinars and not more than (2000) two thousand dinars." For the purpose of the law, art. 2 defines :" Numbers, letters, symbols, shapes, sounds, images or graphics that are not self-evident."

${ }^{9}$ Miles, (fn1) 283.
} 
your location, or where you like spending time. Thus, pictures may lead to exposing your location to criminals.

Taking pictures of celebrities or civilians for commercial purposes is also a wrong that may cause damages. The right to publicity protects both parties. The right to publicity gives an individual the ability to profit and control the commercial use of their images, names or persona. The use of images obtained through street shooting and photography for advertisements without the consent of the people in the photo would influence consumers based on a lie. Using a person's image on a product means that they advocate its use. ${ }^{1}$

\subsection{The Result: Damages}

Damages are the effects caused by the wrongful act. In this case, they are the adverse side effects that may arise from street shooting and photography. Each of the causes can lead to either one or more damages, as will be discussed in this part. $^{2}$ Damages that might accrue include, but not limited to, emotional distress, mental health problems, cyberbullying, defamation, economical loses and becoming a crime victim.

Photography involving acts like shameful, crime scene, humiliating memes, and war photos can lead to emotional distress. As earlier stated, images are a permanent record of an individual. Therefore, if a picture that one would never want other people to see is shared, it leaves a permanent taint on one's personality. ${ }^{3}$ Feelings such as humiliation and anger are associated with such a situation. Legally, emotional distress is called the tort of outrage, where one is entitled to a settlement. The settlement is meant to pay for the recovery of the emotional distress caused by the actions of another person. Psychological distress also leads to a lack of controlling selfregulation, such as one becoming an alcoholic, which ultimately leads to other health issues.

Extreme levels of emotional distress lead to other mental health problems. With mental health problems, one is incapacitated to lead a healthy life, thus depending on others. With mental health cases caused by other's actions, it is tough to prove because, unlike a broken physical part of the body, the condition is not visible. ${ }^{4}$ Mental health conditions that one may suffer in this case include shame, humiliation, depression, anxiety, and stress, which in extreme cases can require a lot of money for medication. In addition, in some cases, mental health issues can lead to suicidal thoughts, thus loss of life. The fear of shame and low self-esteem can lead to isolation, therefore one becoming less productive.

Economically, street photography can cause losses in several ways. In some workplaces, decency and discretion are part of the job requirement. Some photos if taken and shared might lead to losing jobs. ${ }^{5}$ Cases of body shaming, creating funny memes or general cyberbullying with pictures captured in street photography, can lead to reduced self-esteem, which in turn lowers productivity, which can be a reason for losing a job. In addition, due to fear of humiliation and shame, one can choose to quit a career they have been working all their lives to build. Losing the source of livelihood can be very devastating for any individual.

Random pictures of strangers can lead to innocent civilians turning into crime victims. With the level of the current technology, cameras, and other gadgets that capture pictures, such as mobile phones, attach a geotag to the photo. Therefore, the pictures can also tell anyone several other details about a person, such as their favorite location, homes, or the route they use. With the rise of internet use, there are new crimes such as cyberbullying that can be a result of photography. Cyberbullying, which also includes the sharing of private information on the internet, is increasingly threatening people, especially teenagers. Even when street photography is considered as an illegal act from the civil code perspective, the can may lead to anyone to become a crime victim. ${ }^{6}$

\subsection{Link between the Cause and Results}

The link between the cause and the damages is referred to as causation. It is the relationship between the sued party's wrongful behavior and the losses suffered by the plaintiff. For any compensation to happen in a civil liability case, causation has to be established. ${ }^{7}$ In this case, there has to be a relationship between the actions of the street photographer and the effects suffered by the photographed persons. Causation is established by determining two stages: factual causation and legal causation. Factual causation is first created by deciding if the defendant's actions caused the complainant's loss. At this stage, the question of whether the sued did not act in the manner they did, would the plaintiff have suffered injuries is answered. In street photography, the complainant party has to prove that taking their picture caused their suffering. The disadvantage of such cases is when two actions might have contributed to the resulting harm. For example, if someone left their curtain open and their pictures are taken, the lose the right to privacy for their negligence. Legal causation is merely determining whether the defendant's actions can legally be understand to have caused the harm.

\footnotetext{
${ }^{1}$ Miles, (fn1) 274.

${ }^{2}$ Civil Code (n 1).

${ }^{3}$ Zeronda, (fn1) 1136.

${ }^{4}$ Miles, (fn1) 287.

${ }^{5}$ Scott, (fn 1).

${ }^{6}$ Scott, (fn 1).

${ }^{7}$ Civil Code (fn 1).
} 


\section{The Legal Consequences and Treatment of Photography}

Taking pictures of people from the street is legal but also seems to contradict several laws, such as the right to privacy. On one side, the photographer has a right of expression, which is a critical in almost all parts of the world. On the other hand, the stranger whose pictures are taken has a right to be left alone, wherein most legal cases it has been considered that one does not have the right to privacy in public. The case, Nussenzweig v. DiCorcia ${ }^{1}$ is the most common referable example of this study. In the case, a photographer, Philip-Lorca DiCorcia, took hundreds of random photos of strangers in the street. ${ }^{2}$ He chose seventeen pictures and displayed them in a gallery. Among the seventeen pictures, one belonged to Ermo Nussenzweig who was a Hasidic Jew. Nussenzweig sued the act, citing religious and privacy reasons, but the court ruled in favor of DiCorcia, since the photograph had been taken in the street, and was described as art, not commerce. In another case ETW Corporation v. Jireh Publications, ${ }^{3}$ involving Tiger Woods, a celebrity known all over the world, the photographer won the case. ${ }^{4}$ The case ruled that the photographer expressed Wood's success artistically; therefore, the right to privacy and publicity had to yield to right to expression.

In most photography cases, the challenging issue is majorly between the right to privacy, freedom of expression, and critical to publicity. For the photographer to claim their freedom of artistically, they have to prove that their work communicates an artistic message. Therefore, law does not protect the use of cameras; however, the use of photography to engage in expressive conduct is protected.

In Jordan, the only leading case was found that could be helpful for the subject matter of this paper. ${ }^{5}$ In this case the United Nations Children's Fund "UNICEF" offices in Jordan has provided one of the telecommunication companies working in Jordan random photos of individuals of the Jordanian Sociality, including photos of Ibtisam and her sister Ahlam. The later company used this photo alongside other photos of other individuals and put them in pay-as-you- go telephone cards known as (ALO) and then sold them to the public. The two sisters sued the company for the use of their personal photos without their consent. The court decided to compensate bother sisters alongside with the father on the ground that the use of their photos was unlawful act against the personal rights according to article 48 and the father was also compensate on the ground of article 267/1. In this case, the court stated that "[T] he immunity of the human person in its material and moral sense has been guaranteed by all laws, including human rights conventions. Any unlawful assault on one of the inherent rights is prevented. The court also refused the arguments presented by the company that they used the photos per request of the United Nations Children's Fund "UNICEF" on the ground that article 263 of the JCC states that "the act is to be added to the actor, not the person who gave the order to do, unless the act is compelled."

According to the Jordanian law a person has the right to stop the use of his photo once been taken without their consent. This is expressly mentioned in article 48 of the civil code, which states: "Anyone who has been subjected to an unlawful attack on any of the personality rights may request the cessation of such an attack with compensation for the damage he has suffered." In addition, the person who has been photographed without his consent can and at once, and even before filling a caselaw has the right to request from the judge of urgent matters to issue an order to stop the infringement. ${ }^{6}$ In addition, the law gave him the right to request putting under control all illegal copies of photos, in addition, control of proceeds from the illegal exploitation. ${ }^{7}$

The injured person has the right according to the law to be compensated once the previous three elements are proved in the case law. ${ }^{8}$ This is the case when civil lawsuits take place if taking photos or distribution of them if the damage results from any act committed by any of the publications or the audiovisual media. Furthermore, the person who wins the case has the right to request from the court to issue a judgment that includes the publish of the judgment of his case in one or more daily or weekly newspaper at the expense of the other party who lost the case. ${ }^{9}$

Finally, and according to article 29 of the Audiovisual Media Act of $2015^{10}$ the licensee shall be punished if any act was committed that contradict with article $20 / \mathrm{L}$ mentioned earlier by paying a financial fine between 5000-30.000 Jordanian Dinar in addition to compensation and removing the damage caused by the violation.

\footnotetext{
${ }^{1}$ Nussenzweig v. DiCorcia (2007) 848 N.Y.S.2d 7 (NY)

${ }^{2}$ Farley, C. H. (2010). Imagining the Law.

${ }^{3}$ ETW Corp. v. Jireh Publishing, Inc. (2003) 332 F.3d 915

${ }^{4}$ Dreitler, J.R. (2005). Comment: The Tiger Woods Case-Has the Sixth Circuit Abandoned Trademark Law-ETW Corp. v. Jireh Publishing, Inc. Akron L. Rev., 38, p.337.

${ }^{5}$ Case number 3957/2006 - Court of cassion. It should be noted that there are some caselaw on relevant issues but from the criminal law approach such as case number 1636/2019 which was a blackmail case using photos taking without the consent of the person in the photo and case number 1648/2012 which was on Breach of privacy using photos.

${ }^{6}$ art 46 of Law on the Protection of Copyright (fn 1).

ibid.

${ }^{8}$ art 256 JCC and article 42 of Law No. 8 of 1998 (Press and Publication Law of 1998) and its amendments published in the official gazette

issue number 4300 date 01/09/1998 page 3162 .

${ }^{9}$ art 50 of Law on the Protection of Copyright (fn 1).

${ }^{10}$ The Audiovisual Media Act of 2015 (fn1).
} 


\section{Conclusion and recommendation}

This study has reached the following conculsions:

1. Street shooting and photography raises several legal questions since the handheld $35 \mathrm{~mm}$ camera as innovated and sold by Kodak. Before then, photographers who did street shootings and photography had to work from a static position, with difficulties to conceal their identity or work. As technology evolves, it has become more challenging to identify photographers in the street.

2. The Jordanian law recognize some rights, which are connected to the legal personality of human beings. General rules are found within the Jordanian Constitution and the JCC, JCL and other legislative work.

3. The law for both living and non-living individuals protects the right to photography.

4. Any act to taking photos and/or distributing them whether electronically or offline is punishable within the Jordanian laws if done with good or bad intention since no consent was given for photography or the act of publishing.

By the end of this study, the author recommends the following:

1. Introduce all rules that govern the issue of street shooting and photography in one legislation instead of having them shattered in many legislations within the same country. Which make it easier for individuals to know their limits and rights.

2. The need to amend the current JCC by introducing clear texts within the code that covers issues related to the right to photography, rather than having one vague text.

3. There is a need to amend relevant rules on taking and/or publishing photos with bad intention, as the penalties, which are set by the legislator, is not enough with the current technological revolution.

4. There is a need to rise the legal aware of the current legal rules on the subject matter for tourists who are visiting eye catching sites within Jordan and set the limits for them when taking photos of local members of the society and Bedouin life.

5. Initiate a law enforcement body that ensures public safety from such harm and professionals uphold the requirement of their licenses should be initiated.

6. Initiate public education on Jordanian's rights and laws protecting them from street shootings and photography should be initiated.

7. There is a need to rise the legal awareness on issues related to the right of privacy, and the right to photo.

8. Extra research on the problem focusing on criminal side effect that could photography have on the social life of victims and how cold that lead to crime s within the Jordanian society.

\section{References}

Books and Articles

Barron, J. H. (1979). Warren and Brandies, the Right to Privacy, 4 Harv. L. Rev. 193 (1890): Demystifying a Landmark Citation. Suffolk UL Rev., 13, 875.

Center for Global Communication Studies. (2011). Introduction to News Media Law and Policy in Jordan, 2nd edition. Jordan Media Strengthening Program. Retrieved from http://repository.upenn.edu/jordan_program/1

Civil Code, Law No. 43 of 1976. (2018, May 4). Retrieved from https://wilmap.law.stanford.edu/entries/civilcode-law-no-43-1976.

Dreitler, J.R. (2005). Comment: The Tiger Woods Case-Has the Sixth Circuit Abandoned Trademark Law-ETW Corp. v. Jireh Publishing, Inc. Akron L. Rev., 38, p.337. Retrieved from https://heinonline.org/HOL/LandingPage?handle=hein.journals/aklr38\&div=18- \&id=\&page=

Edwards, E. (2016). Photography, anthropology and history: expanding the frame. Routledge. Retrieved from https://books.google.co.ke/books?hl=en\&lr=\&id=cb8FDAAAQBAJ\&oi=fnd\&pg=PP1\& dq=Edwards,+E.,+2016.+Photography,+anthropology+and+history:+expanding+the+fra me.+Routledge.\&ots=-wp9ZUIK2x\&sig $=$ n5DqVzN7VbLJW I4-

VuY7WS7rc\&redir esc $=\mathrm{y} \# \mathrm{v}=$ onepage $\& \mathrm{q}=$ Edwards $\% 2 \mathrm{C} \% 20 \mathrm{E} . \% 2 \mathrm{C} \% 202016 . \% 20 \mathrm{Photo}$ graphy $\% 2 \mathrm{C} \% 20$ anthropology $\% 20$ and $\% 20$ history $\% 3 \mathrm{~A} \% 20$ expanding $\% 20$ the $\% 20$ frame. \%20Routledge.\&f $=$ false

Fatwa number 2948 date 24/01/2014 <https://www.aliftaa.jo/Question.aspx?QuestionId=2948\#.Xb7J29Izbcs> accessed 15/07/2018.

Farley, C. H. (2010). Imagining the Law. Retrieved from https://digitalcommons.wcl.american.edu/facsch_bk_contributions/8/

Gillespie, A. (2006). Tourist photography and the reverse gaze. Ethos, 34(3), pp.343-366. Retreived from https://anthrosource.onlinelibrary.wiley.com/doi/abs/10.1525/eth.2006.34.3.343

Höckert, E., Lüthje, M., Ilola, H. and Stewart, E. (2018). Gazes and faces in tourist photography. Annals of Tourism Research, 73, pp.131-140. 
Khasawneh, M ' Civil Liability of the Journalist for the Violation of the Right to the Image in Jordanian Law' (2015) 12 University of Sharjah Journal of Islamic and Legal Studies 197

Manea, L. (2018). Constants of tort liability's. Bulletin of the Transilvania University of Braşov, Series VII: Social Sciences and Law, 11(2-Suppl), 107-112. Retrieved from https://www.ceeol.com/search/articledetail?id $=745520$

Marvin, J. T. (2015). Without a bright-line on the green line: How Commonwealth v. Robertson failed to criminalize upskirt photography. New Eng. L. Rev., 50, 119. Retrieved from https://heinonline.org/HOL/LandingPage?handle=hein.journals/newlr50\&div $=11 \& \mathrm{id}=\& \mathrm{p}$ age $=$

Mayer, A.E. (2018). Islam and human rights: Tradition and politics. Routledge. Retrieved from https://www.taylorfrancis.com/books/9780429495120

Meltzer, S. (2014, May). The ease of digital photography turns every shutterbug into a potential copyright pirate. Look, but Do Not Shoot.

Miles, M., 2015. Photography, privacy and the public. Law, Culture and the Humanities, 11(2), pp.270-293. Retrieved from https://journals.sagepub.com/doi/abs/10.1177/1743872111430277

Mulki, F. (2008, December). Implementing national copyright laws: a Jordanian case study. In Proceedings of the 2nd international conference on Theory and practice of electronic governance (pp. 191-198). ACM. Retrieved from https://dl.acm.org/citation.cfm?id=1509134

Scott, C., 2013. Street Photography: From Atget to Cartier-Bresson. IB Tauris. Retrieved from https://issuu.com/kmorales15/docs/street_photography___from_atget_to

The Office of the High Commissioner for Human Rights Universal Declaration of Human Rights

Weisenhaus, D., \& Young, S. N. (Eds.). (2017). Media Law and Policy in the Internet Age. Bloomsbury Publishing.

Zeronda, N.D., 2010. Street shootings: Covert photography and public privacy. Vand. L. Rev., 63, p.1131.

\section{Legislations:}

The Jordanian Constitution.

The Jordanian Audiovisual Media Act of 2015 and its amendments, published in the Official Gazette number 5343 page 5614 date $01 / 06 / 2015$.

The Jordanian Civil Code, Law No. 43 of 1976 and its amendments, published in the Official Gazette number 2645 page 2 date $1 / 8 / 1976$.

The Jordanian Criminal Law number 16 of 1960 and its amendments, published in the Official Gazette number 1487 page 374 date 01/06/1960.

The Jordanian Cybercrime Law (Law number 27/2015 published in the official gazette number 5343 date 01/06/2015 page 5631 .

The Jordanian Instructions for Organizing Tourism Activities and Events within the Petra Archaeological Reserve 2017 and its amendments published in the official gazette issue number 5464 date 01/06/2017 page 3836.

The Jordanian Press and Publication Law of 1998 and its amendments, published in the Official Gazette number 4300 page 3162 date $1 / 9 / 1998$.

Instructions for Products of Chemical or Related Industries for 2012 and its amendments published in the official gazette issue number 115 date $01 / 01 / 2012$.

The Jordanian Law on the Protection of Copyright and its amendments, published in the Official Gazette number 3821 page 684 date $16 / 4 / 1992$.

Dr. Enas Qutieshat Has joined Philadelphia University / School of law in 2004-2005. She was then granted a scholarship to the United Kingdom to obtain a PhD in Contract law. She finished her studies at the University of Aberdeen in electronic contracts. Her main research interests lie in electronic contract law and e-commerce fields. 